\title{
Water privatization and public health in Latin America
}

\author{
John P. Mulreany, ${ }^{1}$ Sule Calikoglu, ${ }^{2}$ Sonia Ruiz, ${ }^{2}$ \\ and Jason W. Sapsin ${ }^{3}$
}

Suggested citation Mulreany JP, Calikoglu S, Ruiz S, Sapsin JW. Water privatization and public health in Latin America. Rev Panam Salud Publica. 2006;19(1):23-32.

ABSTRACT Objectives. This study had two objectives: (1) to determine what the public health and development literature has found regarding the public health outcomes of water privatization in Latin America and (2) to evaluate whether the benefits of water privatization, if any, outweigh the equity and justice concerns that privatization raises.

Methods. Using a standard set of terms to search several databases, the authors identified and reviewed articles and other materials from public health and development sources that were published between 1995 and 2005 and that evaluated the public health effects of water privatizations in Latin America from 1989 to 2000, based on (1) access to water by the poor and/or (2) improvements in public health. Next, the authors examined the experiences of three cities in Bolivia (Cochabamba, El Alto, and La Paz) in order to illuminate further the challenges of water privatization. Finally, the authors considered the equity and justice issues raised by the privatization of water.

Results. The literature review raised persistent concerns regarding access to water by the poor under privatization. The review also suggested that the public sector could deliver public health outcomes comparable to those of the private sector, as measured by access rates and decreasing child mortality rates. In terms of social equity and justice, privatization marked a troubling shift away from the conception of water as a "social good" and toward the conception of water-and water management services-as commodities.

Conclusions. Our results indicated there is no compelling case for privatizing existing public water utilities based on public health grounds. From the perspective of equity and justice, water privatization may encourage a minimalist conception of social responsibility for public health that may hinder the development of public health capacities in the long run.

Key words Water supply, privatization, public health, public policy, Latin America.

1 Xavier High School, Religion Department, New York City, New York, United States of America.

2 Johns Hopkins Bloomberg School of Public Health, Department of Health Policy and Management, Baltimore, Maryland, United States of America.

3 Formerly with the Johns Hopkins Bloomberg School of Public Health, Department of Health Policy and Management and with the Johns Hopkins Bloomberg School of Public Health, Center for Public Health Preparedness, Center for Environmental Health Tracking, and Center for Law and the Public's Health, Baltimore, Maryland, United
Access to clean, safe water is a cornerstone of public health, but it re-

States of America. Send correspondence to: Jason W. Sapsin, Assistant Attorney General, Maryland Health Care Commission, 4160 Patterson Avenue, Baltimore, Maryland 21215, United States of America; telephone: (410) 764-3451; fax: (410) 3581236; e-mail: jsapsin@mhcc.state.md.us. (This article does not reflect the position of any agency of the state of Maryland.) mains inadequate in many regions of the world (1). Compared with Asia and Africa, access to (presumably) safe water is higher in Latin America and the Caribbean, with about $78 \%$ of the population obtaining water piped directly through a household connection (2). Rapidly growing urban areas will continue to stretch developing coun- 
tries' abilities to provide the infrastructure necessary for urban water and sanitation. For public health advocates, policymakers, and government officials, there are thus clearly two challenges: (1) increasing water access and (2) developing additional water sources, if necessary, to meet the needs of expanding urban populations.

In the 1980s and 1990s, some advocates proposed privatization in order to combat the problems of inadequate financing for infrastructure and inefficiency in the provisioning of water systems and other public services (3). Important global institutions such as the World Bank have taken prominent roles in introducing the private sector into the reform of state-based water management. Throughout the 1980s and 1990s the Government of the United States of America, the World Bank, and the International Monetary Fund endorsed a development model known as the "Washington Consensus," which was built on the pillars of market liberalization, fiscal austerity, and privatization (4). The Washington Consensus contended that the free market, unimpeded by government interference and corruption, could transform underdeveloped economies.

The privatization of water resources raises at least two questions. The first is whether water privatization improves public health outcomes, compared to public provision of water. We discuss this issue below as it has been presented in the available public health and development literature, briefly considering questions of physical access, the issue of pricing, and, finally, direct measurement of public health improvements. The second question is whether the benefits of privatization of water adequately balance the equity and justice concerns that privatization raises. We explore this question by examining the philosophical assumptions of privatization and consider how these assumptions might influence public health policy, particularly from the perspective of the poor.

Clearly, these two questions are related. The social good of improved public health may justify placing con- trol of water systems in private hands. However, if, for example, privatization preferentially favors the "nonpoor," then it might properly be rejected on equity and justice grounds. We also argue that communities must be aware of how endorsing privatization shapes discussion and thinking about government commitments to social development and public health. In other words, privatization may introduce a more limited view of a government's obligation for promoting public health than a community might desire.

\section{METHODS}

We searched for articles that evaluated the public health effects of water privatization in Latin America based on (1) physical and economic access to water by the poor and/or (2) directly measured improvements in public health due to privatization. In order to capture a wider range of relevant studies, we did not adopt a single, standard definition of the "poor." The studies that we evaluated employed three different definitions of "poor": (1) households with unsatisfied basic needs, (2) households below the poverty line as set by the governments of the countries in the case studies, and (3) households in the bottom deciles of the income distribution of their countries. These different definitions necessitate caution in making generalizations about the poor based on the studies that we located.

Our search used the key words "water privatization" and "Latin America" and "water privatization" and "health" in the PubMed database (United States National Library of Medicine), the Social Sciences Full Text database (H.W. Wilson Web), and the Academic Search Premier (EBSCOhost Research Databases), for peer-reviewed literature published between 1995 and 2005. Only Academic Search Premier indexed articles with the British spelling "privatisation" along with "privatization." Therefore, we performed additional searches in the PubMed and Social Sciences Full
Text databases, substituting "privatisation" for "privatization" in our searches. Noting the importance of development literature for this issue, we also identified relevant studies, consistent with our search terms, from the Web sites of the World Bank Group, the Inter-American Development Bank, and the United Nations University/ World Institute for Development Economics Research. These databases generally utilize American English for English-language articles related to Latin America, so searches using the British "privatisation" spelling were not considered necessary. Also, our searches in these databases did not solely rely on the Web site search engines, but also involved scanning the Web sites. The studies upon which we focus the majority of our discussion compare variables before and after privatization or, alternatively, between privatized and nonprivatized municipalities. We excluded studies from areas other than Latin America, as well as studies that only focused on market profitability or other purely economic issues related to privatization.

Eight studies met our initial search criteria; we summarize them in Table 1 (5-12). Published between 1995 and 2005, these studies evaluated the effects of privatizations in Latin America that occurred between 1989 and 2000. We summarize other studies not of a strictly comparative nature in Table 2 (13-17). Next, to elucidate further the challenges of water privatization, we briefly examine the experiences of three cities in Bolivia: Cochabamba, El Alto, and La Paz. Finally, we consider the equity and justice concerns raised by the privatization of a scarce, essential resource such as water.

\section{RESULTS}

\section{Public health improvement: access and the related issue of price}

Two common measures of the effects of water privatization on public health are increased physical access and economic access (using price). Generally, privatization has positive 
TABLE 1. Empirical studies of the effects of water privatization in Latin America

\begin{tabular}{clll}
\hline Study & Countries & Methodology & Water-related findings \\
\hline Alcázar et al., 2000 (5) & Argentina & $\begin{array}{l}\text { Calculated the gain in consumer surplus based } \\
\text { on Aguas Argentinas records 1992-1997, } \\
\text { using a demand elasticity based on studies of } \\
\text { willingness to pay in similar cities. }\end{array}$ & $\begin{array}{l}\text { Under privatization, new connections increased } \\
\text { by 11\%, and coverage increased from 70\% in }\end{array}$ \\
& & & $\begin{array}{l}1992 \text { to } 83 \% \text { by 1997. Compared to public } \\
\text { provision, consumers were better off by almost } \\
\text { US } \$ 1.33 \text { billion. Gain in consumer surplus } \\
\text { disproportionately benefited high- and middle- } \\
\text { income users. Affordability was a problem for } \\
\text { poorer households. }\end{array}$
\end{tabular}

Barja and Urquiola, 2001 (6) Bolivia $\quad$ Compared pre-reform and post-reform access rates, 1989 to 1999 .

Chisari et al., 1997 (7)

Clarke et al., 2004 (8)

Delfino and Casarin, 2001 (9)

Argentina

Galiani et al., $2003(10)$

Galiani et al., 2002 (11)

McKenzie and Mookherjee, 2003 (12) Argentina,

Bolivia,

Mexico, and

Nicaragua
Argentina

Argentina $^{\mathrm{a}}$

Argentina $^{\mathrm{a}}$

Assessed the macroeconomic and distributional impacts of privatization in electricity, gas, water and sanitation, and telecommunication services by comparing the economy in 1993 and 1995, using a general equilibrium model.

Argentina, Performed a regression analysis on connection Bolivia, and rates in privatized and nonprivatized areas, Brazil based on household surveys before and after privatization taken between 1995 and 2001.

Compared preprivatization and postprivatization prices, 1992 to 1999. Used Household Expenditure Survey data (1998) from Greater Buenos Aires to estimate welfare changes for initial consumers and the surplus of the newcomers.

Performed a difference-in-difference test of the proportion of households with access to a water network in 1991 and 1997 between urban localities where water provision had been privatized and where it had not. Calculated a difference-in-difference estimate of the impact of privatization on child mortality rates between 1990 and 1999.

Performed a difference-in-difference estimate of the change in the proportion of households connected to water services in privatizing and nonprivatizing municipalities from 1991 to 1997. Calculated a difference-in-difference estimate of the impact of privatization on child mortality rates between 1990 to 1999 .

Estimated impact of changes in price and access on the welfare of households, using surveys of income and expenditure between 1984 and 2000.
Foreign investment enabled increases in access to basic services in urban areas. Access improvements did not bypass the urban poor. Evidence from the water sector regarding a privatization/capitalization effect, however, was inconclusive.

Including all utilities, effective regulation benefits all income classes. Ineffective regulation is equivalent to a $16 \%$ implicit tax on the average consumer, paid directly to the owner of the utility; this tax is $20 \%$ for the poorest-income class, and it is lowest for the median-income class.

Privatization positively and significantly correlated with coverage until controlled for time trends and compared to cities that never privatized. In the presence of these controls, the analysis does not reveal any statistically significant correlation between private sector participation and coverage rates.

Water and sewerage prices increased $11 \%$ following privatization. Only $69 \%$ of poorer families benefited from water and sewage services, compared to $89 \%$ of the wealthy. Expenditures for the poor and for the wealthy were $2.7 \%$ and $0.5 \%$ of income, respectively.

Privatization resulted in a statistically significant increase in access to water services. Authors estimate that privatization led to a $5 \%$ decrease in child mortality rates.

Privatizing municipalities experienced significantly larger increases in the proportion of households connected to water services than nonprivatizing municipalities did. Privatization accounted for $4.8 \%$ to $6.7 \%$ lower childhood mortality rates in privatized municipalities than in nonprivatizing municipalities.

Privatization resulted in no clear pattern of price change. Welfare benefit from increased access outweighed the effect of price increases.

\footnotetext{
${ }^{a}$ As they relate to water privatization, both of these Galiani et al. articles present findings from Argentina, using similar data and methodologies. Both studies are relevant because they present slightly different findings and levels of detail. The 2003 article tends to be cited in the literature, but the 2002 article is more detailed on the subject of water. The 2003 article focuses not just on water privatization but privatization more generally in Argentina.
} 
TABLE 2. Other studies related to water privatization in Latin America

\begin{tabular}{|c|c|c|c|}
\hline Study & Countries & Methodology & Water-related findings \\
\hline Ugaz, 2002 (16) & $\begin{array}{l}\text { Argentina, } \\
\text { Bolivia, and } \\
\text { Peru }\end{array}$ & Case studies. & $\begin{array}{l}\text { Absence of competition and lack of } \\
\text { transparency in regulatory procedures still } \\
\text { characterize utility provision after nearly a } \\
\text { decade of privatization. Regulation must } \\
\text { include consumers as stakeholders. }\end{array}$ \\
\hline Zuluaga, 2000 (17) & Chile & $\begin{array}{l}\text { Compared outcomes from regulatory reforms } \\
\text { (not privatization) of the water system } \\
\text { introduced 1989-1990 with a counterfactual } \\
\text { case between } 1989 \text { and } 1998 .\end{array}$ & $\begin{array}{l}\text { Market coverage for water reached } 100 \% \text { soon } \\
\text { after regulatory reform, while sewage coverage } \\
\text { increased from } 88 \% \text { in } 1989 \text { to } 97 \% \text { from } 1994 \\
\text { onwards. Rising prices led to decreases in con- } \\
\text { sumer consumption. Reforms led to substantial } \\
\text { increases in domestic welfare gains. However, } \\
\text { in contrast to the outcome of the Buenos Aires, } \\
\text { Argentina, private concession contract, the } \\
\text { largest beneficiary in Santiago, Chile, was the } \\
\text { government, not consumers. }\end{array}$ \\
\hline
\end{tabular}

effects on physical access to water in Latin America. Galiani et al. (10) show that, in Argentina, household connections to municipal water supplies increased by approximately $11 \%$ from 1991 to 1997 in areas with privatized water services. McKenzie and Mookherjee (12) found that water privatization increased access to clean water by the poor, and the researchers also found some evidence of service improvements. Barja and Urquiola (6) found that access to water under privatization "did not bypass" the urban poor in Bolivia in the capital city of La Paz (population 800 000) and the adjoining city of El Alto (population 750 000). (Though jurisdictionally dis- tinct, La Paz and El Alto are linked geographically and economically. El Alto rapidly grew from a poor shantytown into a large city.)

Nevertheless, the evidence for privatization's superiority in expanding physical access to water relative to public systems is inconclusive. While Galiani et al. (10) point out that the increase in access under privatized localities was greater than under nonprivatized localities, the nonprivatized locations started from a higher proportion of coverage $(86.6 \%)$ than did the privatized locations $(64.0 \%)$. It may be more difficult to gain incremental improvements starting from a higher baseline of coverage, making it under- standable that the gains in the nonprivatized areas would not be as great as in the privatized areas. In addition, the percentage of users with water coverage at the end of the period examined was still greater in the nonprivatized localities $(89.9 \%)$ than in the privatized localities (71.4\%) (10).

Barja and Urquiola (6) found that there was no major difference in the evolution of water access for $\mathrm{La} \mathrm{Paz}$ and El Alto, the two urban centers in Bolivia with privatized systems, versus for comparable urban areas in Bolivia with public systems. Until the short-lived water privatization in Cochabamba in 1999-2000, La Paz and El Alto had the only privatized water 
utilities in Bolivia, having been privatized in 1997. As will be discussed below, the privatization contract for La Paz and El Alto would itself be cancelled as result of public protest in 2005. Although Barja and Urquiola (6) regard the evidence as "somewhat inconclusive," they note that the convergence in water access rates by 1999 in privatized and nonprivatized municipalities suggests that there was not a "strong capitalization/privatization effect" for the privatized areas. In other words, their evidence did not suggest that increased capital from privatization led to greater levels of access to water in the private systems as compared to the public systems.

In addition, studies often estimate access indirectly from service availability per building or neighborhood, combined with reported household expenditures $(9,12)$. In a study of Argentina, Delfino and Casarin (9) reported that water networks in 1997, four years after privatization, reached $76 \%$ of the households of Greater Buenos Aires, an area that includes the federal capital and various nearby communities. In the same study, however, only $55 \%$ of the households declared expenditures for water. The discrepancy between the $76 \%$ of households physically connected to water and the $55 \%$ of households reporting expenditures for water suggests that some households may have been either abstaining from the water supply or illegally accessing the available water. The resulting uncertainty over whether these households can meaningfully be said to have "access" to public water undermines the claim that privatization effectively promotes access to water for all members of a community.

Chisari et al. (14) note that in Argentina the poor can face significant obstacles in obtaining and maintaining access to public utilities. For example, newly supplied utility services to shantytowns entail connection costs and fees, which may cause the poor to relocate to areas that lack those services. Moreover, ongoing service charges need to accommodate the poor's financial vulnerability. The rate of unemployment for households in the lowest income decile in Argentina in January 1998 was over 40\%, and utility expenses can represent $35 \%$ of this decile's total monthly income. Households in this decile are particularly vulnerable to downturns in the overall economy. Not surprisingly, the poor are likely to abandon service networks when they cannot avoid latepayment and delinquency charges.

As noted above, Barja and Urquiola (6) found that the private water system in La Paz and El Alto in 1999 did not bypass the urban poor. Since that time, however, Aguas del Illimani, the water provider to La Paz and El Alto since 1997, failed to keep pace with needs of the burgeoning urban population in $\mathrm{El}$ Alto. In February 2005, in response to popular unrest, Bolivia cancelled its contract with Aguas del Illimani, effective immediately. According to a published news report (18), prohibitively expensive hookup fees and a failure to reach agreement with the government on service expansions left 200000 people without access to the system. No doubt the failure of Aguas del Illimani and the government to reach agreement on service expansions reflects the practical difficulty of reconciling the needs of the poor with profitability.

Long-term price affordability remains a persistent concern under privatization. Lobina and Hall (19) describe how water pricing can change over time, with initial tariff reductions more than offset by later increases. As of February 2005, Aguas Argentinas, one of the largest water concessions in Argentina and whose largest shareholder is French utility group Suez, remained in difficult contract negotiations with the Argentine Government in its efforts to obtain a $60 \%$ rate increase (20). In 1993, the company received the concession to provide water and sewage services covering metropolitan Buenos Aires and fourteen outlying districts. It now serves ten million people in Buenos Aires proper and the seventeen surrounding districts. The request for a substantial rate increase follows heavy losses that the company suffered from Argentina's 2002 freezing of utility rates and con- version of those rates to devalued pesos. Several studies $(7,13,16)$ note the difficulties of implementing appropriate regulatory frameworks for protecting the public from exploitative pricing. Ugaz (16) notes that while regulation has been successful in protecting investors and achieving efficiency gains, rising utility prices cast doubt on how effectively regulation has protected poor consumers. Furthermore, Ugaz notes that the lack of competition and transparency that plagued public utility provision still characterizes private utility provision after a decade of privatization.

\section{Public health improvement: child mortality}

Despite a vast literature on the relationship between clean water and improved public health, only one study in the utility privatization literature addresses the direct effects that the privatizing of water utilities has on public health. Galiani et al. (11) analyze child mortality differences between privatized and nonprivatized water systems in Argentina. Though they do not give exact numerical data for child mortality rates per year, a graph in their study provides approximations of the rates. According to their presentation, the average mortality rate for children aged 0 to 4 years old for privatized and nonprivatized water services in 1995 was about equal-slightly less than 5 children per 1 000. As privatizations increased after 1995, the child mortality rate for privatized municipalities was significantly lower than the rate for their nonprivatized counterparts. In 1998, the year with the greatest observable difference in rates, the child mortality rate for municipalities with nonprivatized water services was somewhat less than 4.5 deaths per 1000 , but for the privatized municipalities the rate was less than 4.0 deaths per 1000 . Controlling for confounding variables, such as income, unemployment, and inequality across municipalities, Galiani et al. (11) estimate that privatization accounted for child mortality rates that were $4.8 \%$ to $6.7 \%$ lower for municipal- 
ities that were privatized than for those that were not privatized between 1995 and 1999. Further, the effect on child mortality was stronger in municipalities with higher levels of poverty. By 1999, however, the mortality rates for privatized and nonprivatized water services were almost identical. According to their graph, the mortality rates for privatized municipalities and nonprivatized municipalities in 1999 were 3.7 and 3.9 per 1000 , respectively. The authors do not explain the similarity of the rates, but the numbers could indicate that the remaining public municipalities performed as well as their private counterparts, as far as providing clean and safe water is concerned. If true, this conclusion is important because it would suggest that private systems do not always outperform nonprivate systemsperhaps only the poorly run or underfinanced systems. If nonprivate systems can operate as well as private systems, the solution to poorly performing nonprivatized systems is not necessarily privatization, but rather better managed and better financed nonprivate systems.

\section{An artificially low baseline resulting from insufficient public investment}

More generally, the studies we reviewed cannot account for the problem of insufficient public investment. Investments in public infrastructure declined steeply in Latin America throughout the 1990s due in part to expectations of privatization (3). This decline may have created an artificially low baseline in terms of water and sanitation infrastructure such as pipes and water mains, against which gains resulting from privatization are magnified both in the before-and-after studies and in the side-by-side studies. Private systems may appear more successful than public systems if the private systems produce rapid increases in the number of households with water access. The comparison, however, is somewhat unfair if the country's tax structure did not generate adequate funds for investment in public systems from the outset. With the ex- ception of the telecommunications industry the growth in private investment in Latin America was insufficient to offset declines in public investments. This has led to a widening gap in infrastructure between Latin America and some East Asian nations (3). Galiani et al. (11) note that deterioration in the performance of water systems in Argentina under public management was so large that it allowed privatization to generate profits, attract investments, expand service, and reduce child mortality.

Advocates view privatization as a way to make up for lack of public financing for infrastructure. However, lack of public resources is itself a function of policy choices. At least in part, Latin America's relatively low tax base hampers public financing for infrastructure. Tax revenue in Latin America is $16.1 \%$ of the gross domestic product (GDP), compared to $28.7 \%$ of GDP in developed countries (3). Low revenues are due in part to low personal income tax collections, which are $1 \%$ of GDP in Latin American countries, but closer to $7 \%$ in developed countries. De Ferranti et al. (3) argue that tax policy in Latin America should be reformed in order to boost public revenues. They recommend instituting a consumption tax that is broad-based but that exempts food and other essential items in order to prevent excessive burdens on the poor, raising personal income tax collections by closing tax loopholes, and generating more revenue from property taxes through higher rates coupled with better property tax administration.

\section{Lessons from Bolivia: the cities of Cochabamba, El Alto, and La Paz}

The example of Bolivia illustrates the public health challenges raised by privatization of public water utilities. In two days of meetings during July 1997 the World Bank urged the President of Bolivia and the Governor of the province of Cochabamba to recognize that privatization of SEMAPA (Servicio Municipal de Agua Potable y Alcantarillado), the semi-autonomous, public water utility for the city of Cochabamba and some of the surrounding area, would solve water supply problems affecting these locations (21). The discussions identified the following problems: insufficient supply of water sources to Cochabamba, SEMAPA's lack of financial resources to expand water infrastructure beyond $60 \%$ of the population, and an insufficient supply of water for agricultural use.

Following the World Bank's recommendation, the Government of Bolivia in 1999 auctioned the rights to Cochabamba's water system to Aguas del Tunari, a consortium comprised of International Water Limited of the United Kingdom, with a 55\% stake (itself a partnership between the Bechtel company of the United States and the Edison SpA company of Italy); Spanish company Abengoa, S.A., with a $25 \%$ stake; and four private Bolivian investors, each with a 5\% stake (22). Under the law, Aguas del Tunari legally gained control of all urban and suburban Cochabamba's surface and subterranean water, including independent cooperatives, rural wells, and irrigation systems, which had never even been part of the SEMAPA network (23).

Shortly after privatization in 1999, water rates in Cochabamba rose on average by $43 \%$ (12). Massive protests ensued over the arrangement, resulting in at least five deaths (24). Ultimately, Bolivia voided the contract in April 2000, returning water provision and administration to SEMAPA and local communities. Aguas del Tunari is seeking as much as US\$ 50 million in compensation for the concession's termination (22). Today, SEMAPA struggles to supply sufficient water for its 56000 household and business users, and its customers must store water in tanks or containers because water is not available continually (25). A 2003 news report indicated that 20000 households were illegally "tapped into" the SEMAPA system and that another 17000 lacked meters necessary to measure consumption and to bill it properly (26).

As noted above, the Bolivian Government recently cancelled its water privatization contract for the cities of La Paz and El Alto. In 1997 the Boli- 
vian Government had contracted with Aguas de Illimani, a subsidiary of the French water company Suez, to run the water systems in $\mathrm{La} \mathrm{Paz}$ and $\mathrm{El}$ Alto. At the time of privatization the state water company offered services to a little over 152000 households. Over the next eight years Aguas de Illimani increased the number of households with service to about 234000 (18). In recent years, however, prohibitively expensive hookup fees and a failure to come to an agreement on service expansion in El Alto left thousands of households (with a total of about 200000 residents) without access to the system. In response to protests, the Bolivian Government cancelled its contract with Aguas de Illimani in January 2005, returning the operation of the water systems in $\mathrm{La}$ Paz and El Alto to public control (18). The failure of privatization in this case is instructive because unlike the privatization fiasco in Cochabamba, which could be written off as a poorly conceived plan, Government officials and academics regarded the plan for private water provision for $\mathrm{La} \mathrm{Paz}$ and El Alto as carefully constructed and "pro-poor" (27). The plan's failure calls into question the viability of privatization as a way to finance water systems for the poor. In 2002, in a presentation to the World Bank water division, the chief executive of SAUR International, a major international water company, also rejected the sustainability of full cost recovery from users in developing countries (28).

The failed privatizations in Cochabamba and subsequently in La Paz and El Alto demonstrate several salient features of water provision that are critically important from a public health perspective. First, these cases corroborate lingering concerns expressed in the scientific literature over water access and pricing for the poor under privatization. Second, the cases underscore that communities justifiably regard water as essential for life and maintain a strong desire for public control of water. Third, the cases remind the World Bank and other international organizations that proposed development strategies must be ac- ceptable to the local populations. Fourth, these cases raise doubts about the financial viability of privatization as a model for extending water services to the poor.

\section{DISCUSSION}

\section{The public health effectiveness of water privatization}

Several considerations qualify our research. First, the different definitions of the "poor" used in the studies that we considered suggest caution in making comparisons about the poor across studies. Second, we limited our article searches to peer-reviewed literature and leading development institutions. Third, we only searched Englishlanguage sources. However, in our view, the literature does not make a compelling case for privatizing existing public water utilities in Latin America based on public health grounds. First, physical access to water for the poor remains a concern under privatization. Second, tariffs for public services may drive the poor into lessdeveloped areas where services are pirated or nonexistent. Third, regulatory frameworks to protect consumers from unacceptable price increases are inadequate. Fourth, evidence suggests that the public sector can deliver comparable public health outcomes as measured by access rates and decreasing child mortality rates. Fifth, the Bolivia cases raise concerns about the financial viability of privatization as a model for extending water systems to the poor.

While the private sector may have the capacity to meet specific public health needs, that sector is necessarily and primarily profit-motivated, not public-health-motivated. The health care system in the United States illustrates the discrepancies that emerge between public health objectives and private sector objectives. In the United States the market allocates resources toward maximizing profit, not achieving optimal public health outcomes. For example, the country can experience a shortage of low-profit, potentially life-saving flu vaccines but have an ample supply of profitable, inessential erectile dysfunction drugs (29). Similarly, one might expect market forces, whether in the United States or in Latin America, to provide water services less effectively to the poor, for whom providing service is less profitable than with the wealthy.

Finally, we hypothesize that, over the long run, privatization discourages the development of local capacity to manage water systems. First, private companies may employ managers from outside the community, particularly at senior levels, hindering the development of local management expertise and capacity. Second, the institution of privatization, despite popular disapproval, may discourage the poor from participating in communitybased public health initiatives. When successful, privatization can discourage participation in local public health initiatives, because public health, like water, may be seen as something for which others are responsible. Of course, privatization brought communities together in Bolivia-to reject privatization-but ideally communities would come together to address health care issues proactively, not in reaction to injustices. Further, advocates for community-based development lose a powerful recruitment and motivating cause when governments disconnect the management of water resources from political mechanisms that hold management accountable to local consumers. Third, privatizing water systems despite popular disapproval suggests a broader unwillingness of governments to collaborate and listen to local communities in the design of successful policies. Listening to the poor and taking into account their conditions is a prerequisite for achieving just policies, because the poor understand the systemic conditions that harm them (30).

\section{Equity and justice concerns: privatization's paradigm shift}

In our view, water privatization represents a troubling shift away from the conception of water as a good requir- 
ing common social management, and towards the conception of water and water management services as commodities that individuals can purchase as they can afford. Water is essential for life. The United Nations has declared that access to sufficient affordable, safe, acceptable water is a human right (31). Gleick et al. (32) call water a "social good" because it improves both individual and social well-being. Kaul (33) identifies water as an "intermediate" global public good, that is, one that contributes to an ultimate global public good of health. Because water is both essential for life and an important social or public good, it is understandable that communities regard public control over water systems as critical. Privatization may make sense for industries where market competition brings efficiency and individuals can exercise choice. Water systems, which are traditionally run as monopolies, are unlike most industries. While there may be competition among providers to acquire a water contract, the municipality awards the contract to only one provider. The nature of water as a scarce, essential, monopolistic resource makes it particularly important that governments guarantee access to it. Privatization of public resources, such as water, may diminish the ability of governments to ensure that the needs of all their citizens are met, because governments are no longer directly in charge of these services.

Privatization is equally troubling on other grounds. It inaugurates a minimalist approach to public health improvement by defining public health issues first in terms of economic viability rather than human need. Privatization is part of a philosophical approach that equates freedom, human rights, and development solely with political and property rights. In this view, governments have a limited obligation to provide for the social and health-related needs of their people. People may purchase basic healthrelated goods and services if they can afford them, but society formally declines to guarantee access to them. Such a view is consistent with the di- minishing public investments seen in Latin America throughout the 1990s in anticipation of privatization. Adoption of pro-privatization policies casts doubt on governments' commitments to development of public health capacities, especially for the poor.

Amartya Sen (34) articulates a richer view of freedom, human rights, and development. In his view, freedom is not merely associated with political and economic rights, but with the fullest development of human capabilities. In this view, basic health care and education are necessary prerequisites for exercising one's human capabilities to the fullest. When these basic needs are met, more substantial freedom is possible than with the freedom that is derived solely from political and economic rights. Development calls for the elimination of sources of "unfreedoms" such as poverty as well as tyranny; poor economic activity as well as systematic social deprivation; and neglect of public facilities as well as repression. This expansive view of freedom, human rights, and development is more compatible with the public health community's desire to promote greater capacity to address global public health needs.

Privatization raises fundamental questions about how a nation and a community are to meet the public health needs of their citizens. Communities are right to question whether privatization affords them enough control of water and other essential resources. Privatization distances government from its responsibility for meeting the needs of its people, and it diminishes the ability of a community to ensure that the needs of all its members are met. Further, privatization and its philosophical assumptions can shape public discussion about public health and other public services. The philosophical basis of privatization suggests a narrow role for government in promoting public health. Citizens should know that it is possible to envision a greater role, rather than a lesser one, for government in the provisioning of public health services, in contrast to the model suggested by privatization.

\section{Alternatives to water privatization}

Several studies suggest a growing awareness of alternatives to water privatization. Trawick (35) proposes a model based on indigenous Andean management principles. Ostrom et al. (36) conclude that there are more solutions for sustainable development than previously thought. They point out that traditional, self-organized group property regimes are sometimes more effective than central government or private corporate management, because they employ time-tested rules that balance the needs of users with the conservation of resources. Sustainable development may require government, private, or traditional management forms, or some combination of them, in order to preserve and use precious resources fairly and intelligently. Hall et al. (37) point to the success of the municipal water system in the city of Porto Alegre, Brazil, as an alternative to privatization. The World Bank, traditionally a proponent of privatization, in its World Development Report 2004 no longer presented private sector provision as the key to improved water and sanitation in urban areas (38). The developing recognition of valid privatization alternatives - that, like privatization, also recognize the need for better management practices and sound financing-is an important trend for public health. Public health and international development professionals must seek to refine and promote these alternatives to wider audiences, including local, national, and global policymakers.

\section{Conclusion}

There appears to be little compelling evidence in the public health literature or the relevant development literature that privatization is the best, or even necessarily a good, route for improving water access and public health. First, there are persistent concerns about access and affordability for the poor under privatization. Second, examples of privatization failures suggest that privatization alone is not a fiscally vi- 
able way for financing service extensions for the poor. Third, privatization misses opportunities to develop local health-related capacities. Not only does privatization take control of critical institutions out of public hands, it lowers expectations of public institutions gen- erally, potentially hindering the development of additional capabilities. Privatization can suggest that public investments are not necessary to address vital needs such as health care for the poor. It shifts the burden for providing services to the poor from society as a whole and back to the poor themselves, and it works against the notion that communities have a shared responsibility to meet the needs of their poorest members. Such a mindset runs counter to public investments in developing health care capabilities.

\section{REFERENCES}

1. World Health Organization. Water, sanitation and links to health [Web site]. Available from: http://www.who.int/water_sanitation_health/ facts2004/en/. Accessed 7 August 2005.

2. WHO/UNICEF Joint Monitoring Programme for Water Supply and Sanitation. Meeting the MDG drinking water and sanitation target: a mid-term assessment of progress, 2004. Available from: http://www.who.int/water sanitation_health/monitoring/jmp2004/en/ [Web site]. Accessed 7 August 2005.

3. De Ferranti D, Perry G, Ferreira FHG, Walton M. Inequality in Latin America and the Caribbean: breaking with history. Available from: http://lnweb18.worldbank.org/LAC/ LAC.nsf/ECADocByUnid/4112F1114F594B4 B85256DB3005DB262?Opendocument [Web site]. Accessed 7 August 2005.

4. Stiglitz J. Globalization and its discontents. New York: Norton; 2003.

5. Alcázar L, Abdala MA, Shirley MM. The Buenos Aires water concession. Available from: http:/ /econ.worldbank.org/external/ default $/$ main?pagePK=64165259\&theSitePK= $469372 \&$ piPK $=64165421 \&$ menuPK $=64166093$ \&entityID=000094946_00042605364386 [Web site]. Accessed 7 August 2005. (World Bank Regulation and Competition Policy Development Research Group Working Paper No. 2311).

6. Barja G, Urquiola M. Capitalization, regulation and the poor: access to basic services in Bolivia. Helsinki: UNU/WIDER; 2001. Available from: http://www.wider.unu.edu/ search/search.htm [Web site]. Accessed $7 \mathrm{Au}-$ gust 2005. (Discussion Paper No. 2001/34).

7. Chisari O, Estache A, Romero C. Winners and losers from utility privatization in Argentina: lessons from a general equilibrium model. Available from: http://econ.worldbank.org/ external $/$ default $/$ main?pagePK $=64165259 \&$ theSitePK $=469372 \&$ piPK $=64165421 \&$ menu $\mathrm{PK}=64166093$ \& entity ID $=000009265$ 3971201161336 [Web site]. Accessed 7 August 2005. (World Bank Group Working Paper No. 1824).

8. Clarke G, Kosec K, Wallsten S. Has private participation in water and sewerage improved coverage? Evidence from Latin America. Available from: http://econ.worldbank. $\mathrm{org} /$ external $/$ default $/ \mathrm{main}$ ?pagePK $=641652$ $59 \&$ theSitePK $=469372 \&$ piPK $=64165421 \&$ menuPK=64166093\&entityID=000012009 20041208141341 [Web site]. Accessed 7 August 2005. (World Bank Policy Research Working Paper No. 3445).
9. Delfino J, Casarin A. The reform of the utilities sector in Argentina. Helsinki: UNU/ WIDER; 2001. Available from: http://www. wider.unu.edu/search/search.htm [Web site]. Accessed 7 August 2005. (Discussion Paper No. 2001/74).

10. Galiani S, Gertler P, Schargrodsky E, Sturzenegger $F$. The costs and benefits of privatization in Argentina: a microeconomic analysis. Available from: http://www.iadb. org/RES/index.cfm?fuseaction=Publications. View\&pub_id=R-454 [Web site]. Accessed 7 August 2005. (Inter-American Development Bank Working Paper \#R-454).

11. Galiani S, Gertler P, Schargrodsky E. Water for life: the impact of the privatization of water services on child mortality. Washington, D.C.: Inter-American Development Bank; 2002. Available from: http://www.iadb.org/ res/publications/pubfiles/pubS-233.pdf [Web site]. Accessed 7 August 2005.

12. McKenzie D, Mookherjee D. The distributive impact of privatization in Latin America: evidence from four countries. Economia. 2003; 3(2):161-233.

13. Chong A, López-de-Silanes F. The truth about privatization in Latin America. Available from: http://www.iadb.org/res/publications/ pubfiles/pubr-486.pdf [Web site]. Accessed 7 August 2005. (Inter-American Development Bank Working Paper \#R-486).

14. Chisari O, Estache A, Waddams Price C. Access by the poor in Latin America's utility reform. Helsinki: UNU/WIDER; 2001. Available from: http://www.wider.unu.edu/search/ search.htm [Web site]. Accessed 7 August 2005. (Discussion Paper No. 2001/75).

15. Parades RM. Redistributive impact of privatization and the regulation of utilities in Chile. Helsinki: UNU/WIDER; 2001. Available from: http://www.wider.unu.edu/search/ search.htm [Web site]. Accessed 7 August 2005. (Discussion Paper No. 2001/19).

16. Ugaz C. Consumer participation and propoor regulation in Latin America. Helsinki: UNU/WIDER; 2002. Available from: http:// www.wider.unu.edu/search/search.htm [Web site]. Accessed 7 August 2005. (Discussion Paper No. 2002/121).

17. Zuluaga AM, Shirley MM, Xu LC. Reforming the urban water system in Santiago, Chile. Available from: http://econ.worldbank.org/ external $/$ default $/ \mathrm{main}$ ?pagePK $=64165259 \&$ theSitePK=469372\&piPK $=64165421 \&$ menu $\mathrm{PK}=64166093$ \& entit $\mathrm{IID}=000094946$ _ 00031605362475 [Web site]. Accessed 7 Au- gust 2005. World Bank Regulation and Competition Policy Development Research Group Working Paper No. 2294).

18. Forero J. Latin America fails to deliver on basic needs. The New York Times. 2005 February 22:A1.

19. Lobina E, Hall D. Problems with private water concessions: a review of experiences in Latin America and other regions. Available from: http://www.psiru.org/reports/200306-W-over.doc [Web site]. Accessed 7 August 2005.

20. Dow Jones Newswire. Agbar: staying with Argentina water concession-report. Dow Jones Newswire. 22 February 2005.

21. Los Tiempos. La posición del Banco Mundial sobre la alternativa más viable para el abastecimiento de agua para la ciudad de Cochabamba. 25 August 1997. Available from: www.aguabolivia.org. Accessed 7 August 2005.

22. Business News Americas. Dep. Min: Aguas del Tunari deal by end-Apr. Business News Americas. 25 March 2004.

23. Farthing L, Kohl B. Bolivia's new wave of protest. NACLA Rep Americas. 2001;34(5):8-11.

24. Quiroga C. Investors flee Bolivia after violent protests. Reuters News Service. 10 April 2000.

25. SEMAPA. La empresa: área de concesión [Web page]. Available from: www.semapa. com.bo/sistema.asp. Accessed 7 August 2005.

26. Los Tiempos. Semapa está en emergencia por déficit de agua potable. Los Tiempos. 12 November 2003. Available from: www.agua bolivia.org. Accessed 15 March 2005.

27. Komives K. Designing pro-poor water and sewer concessions: early lessons from Bolivia Washington, D.C.: World Bank Group; 1999. Available from: http://econ.worldbank.org/ external $/$ default $/$ main?pagePK $=64165259 \&$ theSitePK $=469372 \&$ piPK $=64165421 \&$ menu $\mathrm{PK}=64166093$ \& entit $\mathrm{y} I \mathrm{D}=000094946$ 99121405305313 [Web site]. Accessed $7 \mathrm{Au}-$ gust 2005.

28. Talbot JF. Is the international water business really a business? Available from: http://info. worldbank.org/etools/vod/Presentation View.asp?PID=189\&EID=96 [Web site]. Accessed 7 August 2005.

29. Barlett D, Steele J. The health of nations [editorial]. The New York Times. 2004 October 24

30. Farmer P. Pathologies of power: health, human rights and the new war on the poor Berkeley: University of California Press; 2003.

31. United Nations Economic and Social Council, Committee on Economic, Cultural and Social 


\section{REFERENCES}

Rights. Substantive issues arising in the implementation of the International Covenant on Economic, Social and Cultural Rights. General comment no. 15 (2002). The right to water (Arts. 11 and 12 of the International Covenant on Economic, Social and Cultural Rights). Available from: http://www.unhchr.ch/tbs / doc.nsf/(Symbol)/a5458d1d1bbd713fc1256cc 400389e94?Opendocument [Web page]. Accessed 6 August 2005.

32. Gleick PH, Wolf G, Chalecki EL, Reyes R. The new economy of water: the risks and benefits of privatization of fresh water. Oakland: Pacific Institute for Studies in Development, Environment and Security; 2002. Available from: http://www.pacinst.org/reports/new
economy_of_water/[Web site]. Accessed 7 August 2005.

33. Kaul I. Global public goods and the poor. Development. 2001;44(1):78-84.

34. Sen A. Development as freedom. New York: Anchor Books; 2000.

35. Trawick P. Against the privatization of water: an indigenous model for improving existing laws and successfully governing the commons. World Dev. 2003;31(6):977-96.

36. Ostrom E, Burger J, Field CB, Norgaard RB, Policansky D. Revisiting the commons: local lessons, global challenges. Science. 1999;284: 278-82.

37. Hall D, Lobina E, Viero OM, Maltz H. Water in Porto Alegre, Brazil-accountable, effec- tive, sustainable and democratic. London: Public Services International Research Unit, The University of Greenwich Business School; 2002. Available from: http://www.psiru.org/ reports/2002-08-W-dmae.pdf [Web site]. Accessed 7 August 2005.

38. The World Bank. World development report 2004: making services work for poor people. Available from: http://econ.worldbank.org/ wdr/wdr2004/text-30023/ [Web site]. Accessed 7 August 2005.

Manuscript received 1 April 2005. Accepted for publication 8 June 2005.

RESUMEN Objetivos. Este estudio tuvo dos objetivos: 1) determinar lo que dicen las fuentes bibliográficas sobre sanidad y desarrollo acerca de las consecuencias que puede tener para la salud pública la privatización del abastecimiento de agua en América Latina

La privatización del abastecimiento de agua y la salud pública en América Latina

y 2) determinar si los beneficios de dicha privatización, de haberlos, son mayores que los problemas que plantea en materia de equidad y justicia.

Métodos. Usando ciertas palabras para buscar en varias bases de datos, los autores encontraron y revisaron artículos y otros tipos de materiales obtenidos de fuentes relacionadas con la salud pública y el desarrollo. Se buscaron fuentes publicadas entre 1995 y 2005 donde se evaluaban los efectos para la salud que tuvieron las privatizaciones de los abastecimientos de agua en países de América Latina de 1989 a 2000. Se prestó particular atención a 1) el acceso de los pobres, 2) las mejoras obtenidas en el campo sanitario, o ambas cosas. Posteriormente los autores examinaron las experiencias de tres ciudades de Bolivia (Cochabamba, El Alto y La Paz) a fin de entender mejor los problemas planteados por la privatización. Exploraron, por último, cómo esta repercute en la equidad y la justicia.

Resultados. La revisión de las publicaciones reveló inquietud en torno al acceso de los pobres al agua después de la privatización. Puso de manifiesto, además, que el sector público es capaz de lograr resultados equivalentes a los obtenidos por el sector privado, medidos en función de las tasas de acceso y de la reducción de las tasas de mortalidad de niños menores de cinco años. En lo que respecta a la equidad y la justicia, la privatización marca el comienzo de una tendencia alarmante a concebir el agua y su gestión como bienes de consumo y no como "bienes sociales".

Conclusiones. Nuestros resultados indican que no hay argumentos convincentes de tipo sanitario que respalden la privatización del abastecimiento de agua. Desde el punto de vista de la equidad y la justicia, dicha privatización podría fomentar una visión minimalista de la responsabilidad social en materia sanitaria que a su vez podría menoscabar las funciones del sector de la salud en el largo plazo.

Palabras clave Abastecimiento de agua, privatización, salud pública, política social, América Latina. 